\title{
Армения и Южный Кавказ: новая среда безопасности
}

\section{Энтони Р. Брэнч}

Университет Нью-Йорка, Высшая школа искусств и наук, https://gsas.nyu.edu/

Кавказский научно-исследовательский ресурсный центр - фонд Армения, http://www.crrc.am/

Резюме: В этой статье через линзу реалистической теории международных отношений рассматривается геополитика и среда безопасности на Южном Кавказе и конкретно проблемы безопасности, с которыми столкнется Армения в течение следующих пяти лет. Поскольку Южный Кавказ ограничен соглашениями о коллективной безопасности и затянувшимся конфликтом в Нагорном Карабахе, региональная динамика меняется постепенно. Основой для перспективного анализа являются такие значительные исторические события, как строительство трубопровода Баку-Тбилиси-Джейхан, апрельские события 2016 в Карабахе и завершение Трансанатолийского трубопровода. В этой статье рассматриваются три вопроса. Первый, учитывая меняющийся международный порядок, какой является среда безопасности на Южном Кавказе? Второй, какие геополитические соображения имеют место на Южном Кавказе? Третий, с какими конкретно вызовами национальной безопасности сталкивается Армения? В статье раскрывается, что среда безопасности Южного Кавказа сфокусирована на энергетике, сдвиги в Нагорно-карабахском конфликте зависят от энергетической политики России, и что Россия продолжит сдерживать развитие и независимость Армении, одновременно создавая проблемы для безопасности Армении, с одной стороны, и обеспечивая безопасность Армении, с другой.

Ключевые слова: энергетическая геополитика, Нагорный Карабах, Азербайджан, энергетическая зависимость, коллективная безопасность. 


\section{Цель, охват и основные предположения}

Задача этой статьи состоит в изучении геополитики и среды безопасности на Южном Кавказе и, более конкретно, вызовы безопасности, с которыми столкнется Армения в течение следующих пяти лет.

Геополитика на Южном Кавказе и проблемы безопасности Армении в среднесрочном плане анализируются через линзу реалистической теории. Было бы оправдано посмотреть на пять лет вперед, так как геополитическая среда на Южном Кавказе меняется пошагово. Кроме того, в Армении произошли существенные изменения в управлении, международный порядок тоже меняется.

В этой статье будет рассмотрен сдвиг парадигмы, вызванный завершением Трансанатолийского трубопровода (ТАНАП) и такими значительными событиями, как апрельская карабахская война 2016 года. Опираясь на эти существенные моменты и на академические публикации по вопросу, мы дадим основу для анализа. В этом анализе используются публичная информация и публичные ресурсы, которые в сочетании обеспечивают комплексную и открытую рамку. В этой статье не обсуждается экономика, кроме как политико-экономические аспекты, вопросы внутренней безопасности Армении или любой другой страны, легитимность Республики Нагорный Карабах (или Арцах), коррупция, терроризм, трафик наркотиков или людей. Кроме того, в этой работе не делается попытка составлять прогнозы или давать рекомендации.

В статье делается попытка ответить на три вопроса: Первый, учитывая меняющийся международный порядок, какой является текущая среда безопасности на Южном Кавказе? Второй, какие геополитические соображения имеют место на Южном Кавказе? Третий, с какими конкретно вызовами национальной безопасности сталкивается Армения?

В начале данного исследования было сделано несколько предположений:

- Весьма вероятно, что среда безопасности на Южном Кавказе сфокусирована на энергетике;

- С вероятностью в 50 \% нефтяные запасы Азербайджана исчерпают себя через 24 года;

- Также с вероятностью в 50 \% Армения сможет получить финансирование и построит новую ядерную мощность в течение пяти лет;

- С примерной равной вероятностью в течение следующих пяти лет будет построен и заработает Энергетический коридор «Север-Юг» (ЭКСЮ);

- Статус Нагорно-карабахского конфликта почти наверняка не изменится; 
- Вероятно, в течение следующих пяти лет региональное геополитическое стратегическое превосходство будет у Азербайджана;

- Сближение Турции и Армении в течение следующих пяти лет маловероятно;

- Почти наверняка Россия продолжит сдерживать независимость Армении.

\section{Концептуальная рамка}

Кавказ всегда был исторически значимым регионом мира на перекрестке Центральной Азии, Европы, Ближнего Востока и России. После распада Советского Союза в 1991 году первостепенными проблемами стали независимость государств Сообщества независимых государств и стабильность управления. ${ }^{1}$ После установления легитимных режимов начали делаться международные и региональные усилия по культивированию и развитию природных ресурсов региона; и конкретно ресурсов нефти и природного газа Каспийского моря. ${ }^{2}$ После 2001 года среда безопасности изменилась, включив Войну с терроризмом, ведомую США, и сотрудничество Кавказа с международной коалицией. ${ }^{3}$ Без существенных перемен с 2001 года, среда безопасности изменилась еще один раз, как и международный порядок. ${ }^{4}$ Поэтому, следует рассмотреть современный анализ среды. Этот вопрос еще более актуален в связи с беспрецедентной сменой власти в Армении. ${ }^{5}$ Я намереваюсь заняться этим пробелом в академической литературе рассмотрением исторического развития разной среды безопасности, современных проблем и вызовов, и таким образом провести форвардный анализ текущих вопросов.

\section{Обзор литературы}

В этом обзоре литературы внимание сфокусировано на эволюции среды безопасности, на интересах в сфере безопасности в Кавказском регионе и на конкретных вопросах безопасности в Армении.

1 Richard Giragosian, "Shifting Security in the South Caucasus," Connections: The Quarterly Journal 6, no. 3 (Fall 2007): 100-106, цитата на с. 101, https://doi.org/10.11 610/Connections.06.3.06.

2 Giragosian, "Shifting Security in the South Caucasus."

3 Giragosian, "Shifting Security in the South Caucasus."

4 Rebecca Friedman Lissner and Mira Rapp-Hooper, "The Day after Trump: American Strategy for a New International Order," The Washington Quarterly 41, no. 1 (Spring 2018): 7-25, https://twq.elliott.gwu.edu/sites/g/files/zaxdzs2121/f/downloads/ TWQ_Spring2018_LissnerRappHooper_0.pdf.

5 Alec Luhn, "Armenia Opposition Leader Nikol Pashinyan Elected PM by Parliament," The Telegraph, May 8, 2018, https://www.telegraph.co.uk/news/2018/05/08/ armenia-opposition-leader-nikol-pashinyan-elected-pm-parliament/. 
В 2002 году в своей работе «Армения и проблемы безопасности на Южном Кавказе» Гарник С. Асатрян дал базовую постановку вызовов и интересов Армении в сфере безопасности. ${ }^{6}$ Он фокусирует внимание на нестабильности и нарушениях безопасности на Кавказе, рассматривая их через три призмы: стратегическую, этно-политическую и культурную, причем последние две являются наиболее значимыми. Асатрян идентифицирует несколько стратегических вызовов: соперничество глобальных игроков в борьбе за влияние на Кавказе, парализованная экономическая система, зависимость от международных финансовых структур, борьба за выполнение требований европейских институций, появляющиеся конфликты и коррумпированные политики. Асатрян рассматривает этно-националистическую политику Турции и автономный курдский регион как угрозы для стабильности Кавказа и, в частности, Армении. Он считает, что если кавказские государства смогут сформировать региональную кавказскую идентичность, региональное единство сможет стабилизировать Кавказ. Что касается Армении, Асатрян рассматривает разные динамики. Первая, политические лидеры являются маленькой группой, которая проводит политику в угоду своим личным, а не национальным интересам. Возможно, это изменится после того, как Серж Саркисян ушел в отставку и власть перешла к Николу Пашиняну. Вторая - это продолжающийся экономический упадок и политическое напряжение, связанные с Карабахской войной. Третья, в отличие от соседних государств, Армения имеет этнически однородное население и не испытывает последствия больших политических сепаратистских движений. ${ }^{7}$

В 2004 году Хайк Котанджян, армянский военный дипломат и руководитель Института национальных стратегических исследований и Армянского исследовательского университета национальной обороны, опубликовал статью «Армянская безопасность и внешняя политика США на Южном Кавказе». В этой статье он утверждает, что хотя Армения и Кавказ забыты, Соединенным Штатам необходимо пересмотреть свои интересы в Армении. Он разъясняет, что хотя Армения подписала договор Организации о коллективной безопасности (ОКБ) новых независимых государств, Армения принимает участие в программе НАТО «Партнерство ради мира» (ПРМ) с 1994. Котанджян защищает западную ориентацию Армении в качестве члена Европейского Совета и ее членство в Организации по безопасности и сотрудничеству в Европе (ОБСЕ). Он считает, что в результате уникального баланса между соглашениями о коллективной безопасности с Россией и Америкой,

6 Garnik S. Asatryan, "Armenia and Security Issues in the South Caucasus," Connections: The Quarterly Journal 1, no. 3 (2002): 21-30, https://doi.org/10.11610/Connections. 01.3.04.

7 Asatryan, "Armenia and Security Issues in the South Caucasus." 
Армения предоставляет важную и стратегическую возможность для диалога между Соединенными Штатами и Россией. ${ }^{8}$

В упомянутой выше статье Ричарда Гирагосяна автор описывает историю разной среды безопасности, начиная от независимости кавказских государств после 1991 года до среды после 2001 года. Гирагосян утверждает, что в 1990-х Кавказский регион развивался в основном для добычи энергетических ресурсов, нефти и природного газа из Каспийского моря. После теракта против США от 11 сентября 2001 началась Война с террором. Кавказские государства стали ключевыми партнерами в этой новой Войне с террором, а Соединенные Штаты и Россия вместе использовали территорию, воздушное пространство и сотрудничество с кавказскими государствами для помощи в Афганистане. Гирагосян отмечает в 2007 году, что военная позиция России становится все более антизападной. К 2018 эта тенденция усиливается и может оказать влияние на отношения Армении с европейцами и американцами. Он также отмечает, что Армения является единственным кавказским государством, которое остается приверженным к сильному союзу с Россией, и это остается так и по сей день. Кроме того, он рассматривает политическую и экономическую дружелюбность между Арменией и Ираном в качестве «моста» из Москвы в Тегеран. Партнерство России и Ирана в Сирии только укрепляет эту политическую дружбу. Наиболее примечательный пункт в точке зрения Гирагосяна, это то, что «Легитимность является ключевой определяющей для надежной безопасности и стабильности, а стратегические реалии региона определяются в меньшей степени геополитикой и в большей локальной политикой и экономикой. ${ }^{9}$

Томас де Ваал, известный эксперт по Кавказскому региону, является автором главы «Южный Кавказ в 2020» вышедшей в 2011 книги Россия в 2020: сценарии будущего. ${ }^{10} \mathrm{Oн}$ дает анализ вызовов безопасности, с которыми сталкивается Южный Кавказ. Де Ваал фокусирует свое внимание на культурный аспект Южного Кавказа в качестве призмы для своего анализа. Он констатирует, что молодые поколения, даже в Армении, отдают предпочтение более глобализованной культурной диете в национальных и международных СМИ, а не в российских медиа. Кроме того, все три кавказские государства менее зависимы от России, чем когда-либо, и высказывается предположение, что эта тенденция будет продолжаться. Де Ваал утверждает, что интеграция трудовых ресурсов с Россией создает здоровую взаимозависимость и дает экономические выгоды Кавказу и России. Однако, это лишает Кавказ некоторой части его самой полезной рабочей силы. Де Ваал дает

8 Hayk Kotanjian, "Armenian Security and U.S. Foreign Policy in the South Caucasus," Connections: The Quarterly Journal 3, no. 2 (Summer 2004): 15-32, https://doi.org/ 10.11610/Connections.03.2.03.

9 Giragosian, "Shifting Security in the South Caucasus," 106.

10 Thomas de Waal, "The South Caucasus in 2020," in Russia in 2020: Scenarios for the Future, ed. Maria Lipman and Nikolay Petrov (Washington, D.C.: Carnegie Endowment for International Peace, December 2011), 109-122. 
разбивку по странам и утверждает, что Азербайджан ожидает большой кризис к 2020 году, цитируя данные о неравенстве и коррупции, порожденные богатыми доходами от нефти и газа. В 2018 году Ильхам Алиев снова был переизбран, что, возможно, увеличивает вероятность кризиса к 2020. Он оценивает ситуацию в Армении как политически неустойчивую и видит возможность для расширения с Западом, если будет достигнуто сближение с Турцией и расширены отношения с Европейским Союзом. ${ }^{11}$

\section{Внешние угрозы}

\section{Нагорно-карабахский конфликт и Азербайджан}

Спор вокруг Нагорного Карабаха в 1987 году перерос в вооруженные действия между Арменией и Азербайджаном, которые еще были частью Советского Союза. ${ }^{12}$ Нагорный Карабах является частью горной территории, которая была предоставлена Азербайджану Советским Союзом. Нагорный Карабах имеет историческое и религиозное значение для Армении, поскольку он является исторической частью Армении и имеет преобладающе армянское население. С 1987-1991 имели место совершение погромов и использование вооруженной силы с обеих сторон ${ }^{13}$; в 1992-1994 началась полномасштабная война. При значительном международном давлении и когда число погибших перевалило за 20 000, вооруженные действия были приостановлены в результате соглашения о прекращении огня, достигнутого при посредничестве России в $1994 .^{14}$

Соглашение о прекращении огня от 1994 года является единственным ощутимым дипломатическим успехом в разрешении этого конфликта; все другие мирные переговоры провалились. ${ }^{15}$ В апреле 2016 между Азербайджаном и Арменией снова начались военные действия, известные как Четырехдневная война, ${ }^{16}$ при которых погибли не меньше 200 людей. ${ }^{17}$ В этой войне Армения потеряла часть контролируемой территории, ${ }^{18}$ что являлось

11 Maria Lipman and Nikolay Petrov, eds., Russia in 2020: Scenarios for the Future (Washington, D.C.: Carnegie Endowment for International Peace, December 2011).

12 Stuart J. Kaufman, Modern Hatreds: The Symbolic Politics of Ethnic War (Ithaca, NY: Cornell University Press, May 31, 2001), 62, 49.

13 Kaufman, Modern Hatreds, 49-50.

14 Kaufman, Modern Hatreds, 73-74.

15 Ohannes Geukjian, Negotiating Armenian-Azerbaijani Peace: Opportunities, Obstacles, Prospects (Burlington, VT: Ashgate Publishing Company, 2014).

16 "Nagorno-Karabakh Conflict," Council on Foreign Relations, October 2017, https://www.cfr.org/interactives/global-conflict-tracker\#!/conflict/nagornokarabakh-conflict.

17 “Nagorno-Karabakh's Gathering War Clouds," Europe Report no. ${ }^{\circ 244}$ (Brussels: International Crisis Group, June 1, 2017), https://d2071andvip0wj.cloudfront.net/ 244-nagorno-karabakhs-gathering-war-clouds.pdf.

18 “Nagorno-Karabakh's Gathering War Clouds," 2. 
наглядной демонстрацией прогресса, осуществленного Азербайджаном в сфере военных способностей после 1994 года. Хотя соглашение о прекращении огня постоянно нарушается, ${ }^{19,20}$ за исключением событий в апреле 2016, широкомасштабных насильственных действий после 1994 года не было.

Де факто правительство или "Республика Нагорный Карабах» ${ }^{21}$ использует вооруженные силы Армении и «Арцах»-а для обороны линии контакта и прилегающих контролируемых территорий. У Армении есть причины быть заинтересованной в надежности защиты Нагорного Карабаха, поскольку войной от апреля 2016 Азербайджан доказал, что усиливает свою склонность к военным подходам. Кроме того, азербайджанские войска проходят подготовку под руководством турецких военных как в самом Азербайджане, так и в Нахичеванском анклаве, который граничит с Арменией, Ираном и Турцией. ${ }^{22}$ Хотя Азербайджан продолжает приобретать российское вооружение, ${ }^{23}$ он начал покупать оружие, в том числе ракеты воздух-поверхность, у турции. ${ }^{24}$ Независимо от этого, армянские и карабахские силы должны быть в состоянии сохранить свое тактическое превосходство на земле благодаря тому, что контролируемые ими территории находятся на большей высоте.

Из-за того, что, запасы нефти Азербайджана будут уменьшаться в течение следующих 24 лет, ${ }^{25}$ для режима Алиева будет проблемой в достаточной степени диверсифицировать экономику, готовясь к предполагаемому экономическому шоку. Если экономический кризис грянет, внутренняя политическая атмосфера станет турбулентной, нестабильной и ненадежной для выживания режима Алиева. Поэтому нагорно-карабахский конфликт может стать той внешней приманкой, которая должна отвлечь внимание

19 "Armenian Ceasefire Violation: Azerbaijan's Serviceman Killed," Trend, January 19, 2018, https://en.trend.az/azerbaijan/karabakh/2849943.html.

20 "Nagorno-Karabakh Reports 250 Azerbaijani Ceasefire Violations," Tert, March 3, 2018, http://www.tert.am/en/news/2018/03/03/karabakh/2629054.

21 Надо отметить, что в 2016, де факто правительство Нагорного Карабаха или «Республика Нагорный Карабах» изменила свое имя на «Республика Арцах»; в Армении ее обычно называют «Арцах»-ом.

22 Ilgar Gurbanov, "Interaction with Turkish Air Force Boosts Azerbaijan's Air-Combat Capability," Eurasia Daily Monitor 14, no. 137 (The Jamestown Foundation, October 26, 2017), https://jamestown.org/program/interaction-turkish-air-forces-boostsazerbaijans-air-combat-capability/.

23 Yulia Zhuchkova, "Armenia's Hands Are Tied Regarding Russian Arms Sales to Azerbaijan," The Jamestown Foundation, July 26, 2017, https://jamestown.org/armeniashands-are-tied-regarding-russian-arms-sales-to-azerbaijan/.

24 “Azerbaijan Has Bought SOM Missile from Turkey," Azeri Defence, June 26, 2018, http://en.azeridefence.com/azerbaijan-has-bought-som-missile-from-turkey/.

25 "BP Statistical Review of World Energy: 67 $7^{\text {th }}$ Edition," BP, June 2018, 12, 14, www.bp.com/content/dam/bp/en/corporate/pdf/energy-economics/statisticalreview/bp-stats-review-2018-full-report.pdf. 
общественности от внутренних проблем, козлом отпущения, который сохранит жизнь режиму.

Невзирая на нагорно-карабахский конфликт, расширение азербайджанских трубопроводных проектов склоняет чашу геополитических весов в пользу Азербайджана. Во-первых, инвестируя в мульти-национальные энергетические проекты, прежде всего совместно с Грузией и Турцией, Азербайджан получает возможность экспортировать свои каспийские энергетические ресурсы в Европу, становясь критически важным альтернативным источником, уменьшая постоянную зависимость Европы от России или ближневосточных государств. ${ }^{26}$ Во-вторых, Азербайджан получает прибыль от продажи своих энергетических ресурсов. В-третьих, привлекая Грузию и Турцию в эти проекты, он получает неизбежные, выгодные многим результаты, улучшенные дипломатические отношения, экономические выгоды (совместные доходы и создание рабочих мест) и уменьшение зависимости от российской энергии. Четвертое, кроме как в ТАНАП, главным инвестором во всех азербайджанских энергетических проектах является Бритиш Петролеум, ${ }^{27}$ базированная в Соединенном Королевстве нефтяная корпорация, таким образом усиливая британскую и западную благосклонность к этому богатому энергетическими ресурсами государству.

Благодаря этому геополитическому преимуществу Азербайджана, Армения проигрывает в трех аспектах. Во-первых, Армения теряет влияние в грузино-армянских отношениях, поскольку Грузия предпочитает Азербайджан в качестве более выгодного и прибыльного партнера. Грузия стремится к ослаблению своей зависимости от России, а азербайджанские проекты трубопроводов дают занятость, финансовые выгоды и энергию. Во-вторых, трое из четырех соседей Армении становятся более богатыми в результате этих энергетических партнерств, таким образом увеличивая финансовый разрыв между Арменией и ее соседями. В-третьих, Азербайджан добивается существенного улучшения отношений с европейскими странами в качестве необходимой энергетической альтернативы, особенно в свете того, что отношения Запада и России продолжают ухудшаться, ${ }^{28}$ таким образом, придавая Азербайджану большую ценность, чем Армении, несмотря на более европейское управление и ценности Армении. Это может уменьшить поддержку или нарушить нейтралитет для Армении в нагорно-карабахском конфликте.

26 Armen Manvelyan, Energy Security and Geopolitical Challenges in the CaucasusCaspian Region (Yerevan, Armenia: Yerevan State University, 2015), 194, 198.

27 Manvelyan, Energy Security and Geopolitical Challenges, 193.

28 Gardiner Harris, "U.S. To Issue New Sanctions on Russia Over Skripals' Poisoning," The New York Times, August 8, 2018, https://nyti.ms/20Uvbvo. 


\section{Турция}

Хотя турецко-армянские отношения никогда не были хорошими, ${ }^{29}$ возможность сближения после получения Арменией независимости от СССР была сведена на нет, когда Турция стала на сторону Азербайджана после начала нагорно-карабахского конфликта. Хотя Турция признала Армению в качестве независимого государства в 1991, она закрыла свою границу с Арменией в 1993 в поддержку Азербайджана в нагорно-карабахской войне. ${ }^{30}$ В 2008-2009 Турция попыталась нормализовать свои отношения с Арменией, но инициатива провалилась в результате сильного давления со стороны Азербайджана, который сумел сделать прогресс в нормализации армянотурецких отношений зависящим от принятия его предложений по улаживанию нагорно-карабахского конфликта. ${ }^{31}$ В ближайшем будущем нормализация отношений между Ереваном и Анкарой не представляется возможной. Недоверие армян к Турции возросло, а внутренняя поддержка сближения уменьшается.

Хотя турецко-армянские отношения не улучшаются, весьма маловероятно, что турецкие войска пересекут границу и нападут на Армению. Во-первых, Армения является подписантом в Организации Договора о Коллективной Обороне (ОДКБ) и Россия является гарантом ее безопасности. Во-вторых, Соединенные Штаты и другие члены НАТО определенно не заинтересованы в своем вовлечении в небольшой региональный конфликт, который может перерасти в войну с Россией. В-третьих, Армения больше не занимает приоритетное место среди внешнеполитических интересов Турции. С учетом сирийского конфликта на турецкой границе, внутренних волнений и разделения среди населения, проблем в отношениях с Грецией по поводу средиземноморских островов и Кипра, а также ухудшения отношений с Соединенными Штатами, Турция на данный момент не заинтересована в сближении или в нападении на Армению.

В 2010 году Турция и Азербайджан подписали Соглашение о стратегическом партнерстве, ${ }^{32}$ далее ослабляя возможность об установлении дипломатических отношений с Арменией. Военное партнерство с Азербайджаном

29 Fiona Hill, Kemal Kirişci, and Andrew Moffatt, "Armenia and Turkey: From Normalization to Reconciliation," Brookings Institution, February 24, 2015, https://www.brookings.edu/articles/armenia-and-turkey-from-normalization-toreconciliation/.

30 Audrey L. Altstadt and Rajan Menon, "Unfrozen Conflict in Nagorno-Karabakh: Why Violence Persists," Foreign Affairs, April 12, 2016, https://www.foreignaffairs.com/ articles/armenia/2016-04-12/unfrozen-conflict-nagorno-karabakh.

31 F. Stephen Larrabee and Alireza Nader, "Central Asia and the Caucasus," in TurkishIranian Relations in a Changing Middle East (Santa Monica, CA: RAND Corporation, 2013), 19-20, https://www.rand.org/pubs/research_reports/RR258.html.

32 Zaur Shiriyev, Eka Tkeshelashvili, and Mitat Celikpala. "Institutionalizing a Trilateral Strategic Partnership: Azerbaijan, Georgia, Turkey," Policy Paper (Konrad Adenauer Stiftung, 2016), 12, http://www.kas.de/wf/doc/kas_43884-1522-1-30.pdf. 
в последние годы расширилось как по частоте, так и по охвату совместных военных учений на основной территории Азербайджана и в Нахичеванском анклаве. $^{33}$ Тогда как Азербайджан рассматривает это стратегическое партнерство как противовес российско-армянскому военному партнерству, Турция воспринимает его как гарантию непрерывности потока энергетических ресурсов из бассейна Каспийского моря. ${ }^{34}$

В историческом плане, географическое место Турции было одним из наиболее важных геостратегических местоположений в мире, и сейчас оно все еще является таким. Сегодня Турция использует свое геостратегическое положение для осуществления поставок энергии с Ближнего Востока и Кавказа в Европу. Поскольку Турция не так богата, как ее соседи, запасами энергетических ресурсов, она позиционирует себя в качестве главного посредника при транзите нефти и природного газа, ${ }^{35}$ а нефтепровод Баку-ТбилисиДжейхан и газопровод ТАНАП имеют ключевое значение.

\section{Энергетическая геополитика и есть Новая среда безопасности}

Энергетическая геополитика формирует новую среду безопасности на Южном Кавказе. Хотя Южный Кавказ всегда был в фокусе энергетической политики, завершение ТАНАП ${ }^{36} 12$ июня 2018 года затвердило полный переход к энергетически доминированной среде безопасности.

Если не считать Россию, Азербайджан является наиболее богатой энергетическими ресурсами государством на Кавказе. ${ }^{37}$ Как показано выше, Азербайджан действует и получает выгоду от своих многонациональных энергетических проектов многоаспектным способом, бросая вызов балансу сил на Южном Кавказе. Несмотря на это, Россия есть и продолжит быть наиболее сильным энергетическим и военным игроком на Кавказе. Россия располагает огромными запасами нефти и природного газа по сравнению со своим кавказским партнером. Хотя официальная российская позиция на Кавказе нейтральна в отношении всех государств, она неявно (а иногда и открыто) в наибольшей степени совпадает с позицией Армении. И наоборот, Армения чаще всего придерживается к позиции России и является единственной страной на Кавказе в таком положении. ${ }^{38}$

Из-за нагорно-карабахского конфликта Армения была исключена из энергетических сделок Азербайджана с Грузией и Турцией. Поэтому она

33 Shiriyev, Tkeshelashvili, and Celikpala, "Institutionalizing a Trilateral Strategic Partnership," 14.

34 Larrabee and Nader, "Central Asia and the Caucasus," 19.

35 "BP Statistical Review of World Energy: 67 ${ }^{\text {th }}$ Edition," 22-23.

36 "Reference Documents," TANAP Natural Gas Transmission Company, https://www.tanap.com/reference-documents/.

37 "BP Statistical Review of World Energy: 67 ${ }^{\text {th }}$ Edition," 12, 26.

38 Collective Security Treaty Organization, http://www.odkb.gov.ru/start/index_aen gl.htm. 
была вынуждена искать возможностей для повышения своей энергетической безопасности. ${ }^{39}$ Это стало приглашением для России инвестировать в Армению и, в результате, доминировать над и контролировать ее энергетический сектор. Партнерство Армении с Россией не только позволило обеспечить безопасность армянского энергетического сектора, но и дает Армении излишки энергии, которые она может продавать на региональных рынках. Поэтому Армения вошла в Евразийский Экономический Союз (ЕЭС).

Хотя эти азербайджанские энергетические проекты сыграли стабилизирующую роль в региональной среде безопасности, они так же сделали мир и стабильность зависимыми от международных цен на нефть. ${ }^{40}$ Поэтому, когда глобальные цены на нефть существенно снизились после 2014, ${ }^{41}$ уменьшающаяся роль Азербайджана в регионе и снятие нефтяных санкций с Ирана способствовали региональной нестабильности. Результаты этой нестабильности и усиление конфронтации наблюдались в нагорно-карабахской войне от апреля 2016. Сдвиг, имевший место с 2014 по 2016 позволил в результате взаимодействия России и Ирана развить инициативу запланированного Энергетического Коридора «Север-Юг» (ЭКСЮ), которая включает Армению и Грузию в качестве транзитных государств для российской и иранской энергии, что привело к изменению геополитического баланса сил. ${ }^{42}$ В частности, она создаст противовес - в финансовом и дипломатическом плане - азербайджано-турецкому энергетическому сотрудничеству.

В дополнение к влиянию снижения международных цен на нефть на региональное положение Азербайджана, запасы ископаемого топлива России намного больше запасов Азербайджана, что приводит к более устойчивой ситуации. Нефтяные запасы России оцениваются в 106.2 миллиардов баррелей, а ее запасы природного газа составляют 35 триллионов кубических метров, по сравнению с 7 миллиардами баррелей нефти и 1.3 триллионами кубических метров газа Азербайджана. ${ }^{43}$ Очевидно, азербайджанские проекты намного меньше, чем глобальные проекты России, но это только региональный анализ.

39 Armen Manvelyan, "The Implications for Eurasian Economic Union and South Caucasus Energy Policy" (Yerevan: Institute of Oriental Studies, National Academy of Science, April 2018), доступно на https://www.researchgate.net/publication/324532 430_armen_manvelyan_the_implications_for_eurasian_economic_union_south_cau casus_energy_policy.

40 Manvelyan, "The Implications for Eurasian Economic Union," 21.

41 "Crude Oil Prices Down Sharply in Fourth Quarter of 2014," U.S. Energy Information Administration, January 6, 2015, https://www.eia.gov/todayinenergy/detail.php?id= 19451.

42 Manvelyan, "The Implications for Eurasian Economic Union," 22.

43 "BP Statistical Review of World Energy: 67 $7^{\text {th }}$ Edition," 12, 26. 
Азербайджан рассматривает свою зависимость от своих нефти и газа как одну из самых больших внутренних угроз. ${ }^{44}$ При нынешнем темпе выработки и если не будет каких-либо дальнейших открытий месторождений, нефтяные запасы Азербайджана будут исчерпаны через приблизительно 24 года. ${ }^{45}$ Хотя по текущим оценкам природного газа Азербайджана хватит на гораздо больший период, но прибыль от него гораздо меньше. Это означает, что Азербайджан будет вынужден не только диверсифицировать свою экономику, чтобы подготовиться к экономическим трудностям, но в то же самое время ему придется найти и способ подтвердить свою ценность для региональных и европейских партнеров. Азербайджану хорошо известно значение его региональных стратегических партнерств с Грузией и Турцией, как заявил Алиев, в качестве главного приоритета в сфере национальной безопасности нужно сохранять «... трехстороннее стратегическое партнерство и углубляющееся сотрудничество между Азербайджаном, Грузией и Турцией». ${ }^{46}$ Если Азербайджан не дополнит свою нефть другими товарами (ресурсами или услугами), его национальная безопасность и стабильность подвергнутся большому риску.

При нынешнем состоянии Южного Кавказа - группа государств, связанных гарантиями безопасности (за исключением Грузии) - баланс сил может быть существенно изменен только в результате энергетической геополитики. В этом плане, Армении нужно построить новую атомную электростанцию. Существующая станция, построенная в 1970-х еще при СССР, уже устарела. ${ }^{47}$ ЕС считает ее состояние неприемлемым и настаивал на ее выводе к 2016 году. Тогда Россия восстановила ее критические компоненты для увеличения срока ее жизни на 10 лет. ${ }^{48}$ Поэтому, к 2026 году Армения должна располагать новой и функционирующей атомной станцией, поскольку она обеспечивает 40 \% электричества Армении. Единственным препятствием перед ее строительством является отсутствие финансирования. Проект потребует для строительства пять миллиардов долларов США; на данный момент, единственным донором является Россия, которая предлагает 4.5 миллиарда долларов. ${ }^{49}$

Новая электростанция не только обеспечит Армению соответствующей мощностью для производства электричества, но позволит ей и продавать излишки ее соседям, например Грузии, Ирану и другим государствам СНГ.

44 Hayk Kocharyan, "Regional Security Dynamics: Azerbaijan," Analytical Bulletin: Center for Civilization and Cultural Studies (2017), c. 76.

45 "BP Statistical Review of World Energy: 67 $7^{\text {th }}$ Edition," 12, 14.

46 Kocharyan, "Regional Security Dynamics: Azerbaijan," 86.

47 Armen Manvelyan, "Energy Security in Armenia: Challenges and Opportunities," in The South Caucasus 2018: Facts, Trends, Future Scenarios (Tbilisi: Konrad Adenauer Stiftung, 2013), 127-128, 137.

48 "Nuclear Power in Armenia," World Nuclear Association, March 2018, www.worldnuclear.org/information-library/country-profiles/countries-a-f/armenia.aspx.

49 "Nuclear Power in Armenia." 
Возможно, для ЕС или Франции было бы проявлением мудрости способствовать финансированию этого проекта, поскольку это ускорит создание безопасного ядерного функционирования и обеспечит возврат инвестиций ЕС через экономические, энергетические и дипломатические выгоды. Так же, этот проект дает возможность активизировать отношения между Арменией и Грузией в результате уменьшения зависимости от российской энергии.

Дополнительным фактором является решение администрации Трампа вывести Соединенные Штаты из СВПД (Совместного всеобъемлющего плана действий) по Ирану. ${ }^{50}$ Выходя из сделки, Соединенные Штаты заново наложат строгие санкции на Иран ${ }^{51}$ и на фирмы союзных стран, которые ведут дела с Ираном, что вынудит Иран отчаянно искать региональных партнеров. Армения может воспользоваться этой возможностью, в частности, в связи с новым ядерным сооружением. Рассматривая эти стратегические энергетические ходы, Армения может найти возможность для получения финансовых и дипломатических выгод и для стратегического ребаланса отношений в сфере энергетики.

\section{Роль России}

Российско-армянские отношения имеют длинную историю, более значительные события которой начинаются после заключения Туркманчайского договора между Персией (Ираном) и Россией в 1828 году, в котором указывалось, что Россия займет территорию, предназначенную для размещения армянского населения. ${ }^{52}$ С точки зрения многих армян, русские спасли армян от турков во времена геноцида, обеспечив им безопасность в Советском Союзе. ${ }^{53}$ За исключением короткого периода независимости в 1917 , Армения стала суверенным государством в 1991 после 70 лет советской власти. ${ }^{54}$

Хотя Россия является гарантом энергетической и военной безопасности Армении, главным ее торговым партнером и союзником, Россия не только помогает, но и мешает развитию Армении. Во-первых, из-за нагорно-карабахского конфликта с Азербайджаном, Армения испытывает внутренние,

50 Mark Landler, "Trump Abandons Iran Nuclear Deal He Long Scorned," The New York Times, May 8, 2018, https://nyti.ms/2KMeG2f.

51 "Executive Order Reimposing Certain Sanctions with Respect to Iran," The White House, August 6, 2018, https://www.whitehouse.gov/presidential-actions/executiveorder-reimposing-certain-sanctions-respect-iran/.

52 "The Treaty of Turkmenchay between Russia and Iran Signed," Russian Federation Presidential Library, February 22, 1828, https://www.prlib.ru/en/history/619048.

53 Razmik Panossian, "Post-Soviet Armenia: Nationalism \& Its (Dis)contents," in After Independence: Making and Protecting the Nation in Postcolonial and Postcommunist States, ed. Lowell W. Barrington (Ann Arbor, MI: The University of Michigan Press, 2006), 226, https://www.press.umich.edu/pdf/0472098985-ch9.pdf.

54 Panossian, "Post-Soviet Armenia," 225-226. 
региональные и международные отрицательные последствия, как было указано выше. Хотя Россия не участвует в конфликте, она является единственной силой, которая может односторонним образом закончить конфликт. Однако, без России и ее гарантий безопасности Армении конфликт также не может быть разрешен. Более того, по многим причинам не в интересах России закончить нагорно-карабахский конфликт - на первом месте из-за того, что он позволяет России сохранять определенную степень контроля над двумя бывшими советскими республиками через (экономическую, военную и дипломатическую) зависимость, и на втором месте, Россия располагает возможностью получать финансовые выгоды от продажи оружия как Армении, так и Азербайджану.

Во-вторых, хотя Армения стремится к энергетической независимости, она зависит от российских государственных компаний, которые почти монополизировали энергетический сектор Армении; 55 это включает атомную станцию Метсамор, которая эксплуатируется российской дочерней компанией. ${ }^{56}$ Кроме того, попытки Армении добиться энергетической независимости через такие альтернативные источники как гидроэлектрические, солнечные, ветровые станции или через строительство новой ядерной мощности сдерживаются отсутствием финансирования. ${ }^{57}$ Поэтому, Россия обеспечивает финансирование этих проектов при условии, что российские компании будут получать прибыль от них в обмен на инвестиции. ${ }^{58}$ Таким образом, на практике Армения все еще не может добиться энергетической независимости.

В-третьих, поскольку Армения зависима от российской нефти и российского газа, она присоединилась к Евразийскому Экономическому Союзу (ЕЭС) в 2013, чтобы и дальше получать субсидии на свой энергетический импорт. ${ }^{59}$ Существует также предположение, что в свете интереса ЕС к Армении, Россия неявным образом оказала давление на Армению, чтобы она вошла в ЕЭС для того, чтобы Россия могла в большей степени ее контролировать. ${ }^{60}$ Несмотря на успех Армении в переговорах с ЕС и ЕЭС, ${ }^{61}$ ЕЭС все еще

55 Paul Stronski, "Armenia at Twenty-Five: A Rough Ride," Carnegie Endowment for International Peace, December 6, 2017, https://carnegieendowment.org/2016/12/07/ armenia-at-twenty-five-rough-ride-pub-66351.

56 "Nuclear Power in Armenia."

57 "Nuclear Power in Armenia."

58 "Nuclear Power in Armenia."

59 Pasquale De Micco. "When Choosing Means Losing: The Eastern Partners, the EU, and the Eurasian Economic Union," European Parliament, March 2015, 20, http://greatereurope.org/archives/5742.

60 "Armenia Joins Eurasia Union," Radio Azatutyun, Radio Free Europe/Radio Liberty, January 3, 2015, https://www.azatutyun.am/a/26774782.html.

61 Emil Danielyan, "EU Reveals Landmark Deal with Armenia," Radio Azatutyun, Radio Free Europe/Radio Liberty, October 16, 2017, www.azatutyun.am/a/28798353.html. 
мешает Армении заключать деловые соглашения с Западом, что диверсифицировало бы ее партнеров.

Четвертое, экономика Армении зависит от денежных переводов армян, работающих сезонно или постоянно в России. Около 14 \% ВВП создается этими переводами, 62 что дает России еще один рычаг для воздействия на армянскую политику и экономику.

Пятое, Армения страдает от западных санкций, наложенных на Россию. Из-за ухудшения отношений между Россией и Западом, после предполагаемого вмешательства России в выборы в США и покушения на Сергея Скрипаля и его дочь в Солсбери, Соединенное Королевство, на Россию были наложены еще санкции. Армения испытывает прямые последствия от них, поскольку санкции направлены против российских олигархов, которые контролируют такие компании, доминирующие в армянской экономике, как Газпром и Роснефть. ${ }^{63,64}$

\section{Заключение: варианты для Армении}

Хотя Армения находится в геополитически невыгодном положении в регионе, у нее есть возможности, которые следует рассмотреть. Во-первых, Армения должна стремиться к нахождению решения нагорно-карабахского конфликта; предпочтительнее всего через Минскую группу Организации по безопасности и сотрудничеству в Европе. Если будет улажен конфликт между Азербайджаном и Арменией, многие из проблем, с которыми сталкивается Армения, начнут исчезать по мере того, как налаживаются отношения, открываются границы и развивается торговля.

Во-вторых, Армения может диверсифицировать и развить свой энергетический сектор. Этот процесс можно начать поиском международного финансирования для развития альтернативных источников энергии (ветряные, солнечные, гидро). Это уменьшит зависимость от российской энергии и даст Армении больший излишек для продажи на региональных рынках. Кроме того, было бы разумно, чтобы Армения профинансировала и построила новую работающую ядерную мощность к 2026 году, чтобы обеспечить стране достаточную подачу энергии. Если Армения сможет получить финансирование от разных международных инвесторов, а не только единственно от России, это позволило бы Армении еще ослабить свою зависимость и уменьшить свою задолженность России.

62 "Personal Remittances, received (\% of GDP)," The World Bank, 2018. https://data.worldbank.org/indicator/BX.TRF.PWKR.DT.GD.ZS?locations=AM.

63 "Sectoral Identifications List," Office of Foreign Assets Control, U.S. Department of Treasury, July 25, 2018, 4 и 51, https://www.treasury.gov/resource-center/ sanctions/SDN-List/Pages/ssi_list.aspx.

64 "Enforcement Information for July 20, 2017," Office of Foreign Assets Control, U.S. Department of Treasury, July 20, 2017, 1, https://www.treasury.gov/resourcecenter/sanctions/CivPen/Documents/20170720_exxonmobil.pdf. 
В-третьих, учитывая завершение ТАНАП и наложение снова санкций на Иран, развитие Энергетического Коридора «Север-Юг» было бы мудрым решением.

\section{Благодарности}

Я высказываю благодарность докторской программе «Пути» Высшей школы науки и искусств Университета Нью-Йорка за финансирование этой исследовательской инициативы, а также Кавказскому научно-исследовательскому ресурсному центру - Армения за поддержку и покровительство моей работы.

\section{Об авторе}

Энтони Р. Брэнч - аспирант Университета Нью-Йорка. Летом 2018 года он жил в Ереване, Армения, в качестве международного сотрудника Кавказского научно-исследовательского ресурсного центра - фонд Армения, где он вел свое исследование, используя первичные и вторичные источники, беседовал с ведущими местными интеллектуалами и выучил армянский язык. Эго работа уже принята к публикации в Журнале политических исследований Университета Нью-Йорка.

E-mail: arb744@nyu.edu. 